\title{
A CLOSER LOOK AT THE PROPOSED LATE-WISCONSIN- WEICHSELIAN ARCTIC ICE SHEET
}

\author{
By J. L. Fastook, R. Sweet, \\ (Department of Physics, University of Maine, Orono, Maine 04473, U.S.A.)
}

and T. J. Hughes

(Department of Geological Sciences and Institute for Quaternary Studies, University of Maine, Orono, Maine 04473 , U.S.A.)

Abstract. The CLIMAP is ooo years B.P. experiment required reconstructing lateWisconsin-Weichselian ice sheets. In the Northern Hemisphere, the greatest uncertainty in these reconstructions is the area covered by ice sheets. Two schools of thought exist (Hughes and others, in press). The minimum-ice-sheet school holds that ice sheets originated from present ice caps in the High Arctic islands, but the northern seaward margins of these ice sheets retreated as the southern landward margins advanced. This occurred because northern margins became isolated from sources of precipitation as Arctic seas became permanently ice-covered and the advancing southern margin changed atmospheric circulation patterns. In this view, these ice sheets stay about the same size and migrate southward during an ice age. Northern margins rarely reach sea-level during the later stage of the ice age so no marine portions form and ablation is by melting or sublimation. Marine portions formed only when the ice sheets migrated across shallow seas between the High Arctic islands and the mainland. At the end of the ice age, huge amounts of heat had to be transferred from the tropics to the ice sheets in order to account for late-Wisconsin-Weichselian and Holocene retreat-rates by melting along ice-sheet margins.

A quite different picture emerges from the maximum-ice-sheet school, which holds that ice sheets formed almost uniformly from thickening snowfields and sea ice over the lands and seas of the Arctic and sub-Arctic. The marine portions were inherently unstable and collapsed from time to time, giving interstadials during an ice age. Temporary stabilization occurred when confined ice shelves formed over the deep ocean basins so that ice streams draining marine portions of these ice sheets were buttressed in the way West Antarctic ice streams are buttressed today (Hughes and others, 1977; Denton and Hughes, in press).

Northern ice-sheet margins did not retreat as southern margins advanced because, with the buttressing ice shelves, they were always in a positive mass-balance regime even if snow precipitation rates reduced drastically. Final collapse of these ice sheets occurred when climatic warming melted back the ice shelves, allowing marine portions to surge. Calving bays migrated up the surging ice streams draining marine portions of the ice sheet so that collapse was mainly by iceberg calving instead of by surface melting. Ocean currents carried these icebergs toward the equator so that ice was brought to the heat by the oceans instead of having the atmosphere bring heat to the ice, as the minimum school requires.

A resolution between these conflicting schools of thought is necessary not only for correctly reconstructing ice sheets for the CLIMAP 18 ooo years B.P. experiment, but also for understanding what controls ice-age cycles. The minimum school proposes several isolated ice sheets of nearly constant size migrating equatorward in response mainly to their atmospheric interfaces. The maximum school proposes a single, unified Arctic ice sheet expanding and contracting in place in response mainly to its oceanic interface. Evidence for and against each school is reviewed and further research needed to resolve this problem is discussed. 


\section{REFERENCES}

Denton, G. H., and Hughes, T. J. In press. The Arctic ice sheet: an outrageous hypothesis. (In Denton, G. H., and Hughes, T. J., ed. The last great ice sheets. New York, Wiley-Interscience.)

Hughes, T. J., and others. 1977. Was there a late-Würm Arctic ice sheet? [By] T. J. Hughes and G. H. Denton, M. G. Grosswald [i.e. Grosval'd]. Nature, Vol. 266, No. 56o3, p. 596-6o2.

Hughes, T. J., and others. In press. The last great ice sheets: a global view, by T. [J.] Hughes, G. H. Denton, B. G. Andersen, D. H. Schilling, J. L. Fastook, and C. S. Lingle. (In Denton, G. H., and Hughes, T. J., ed. The last great ice sheets. New York, Wiley-Interscience.)

\section{DISCUSSION}

L. A. Lliboutry: Why did you not take the lag of isostatic rebound into account?

T. J. Hughes: CLIMAP atmospheric circulation models for the maximum interglaciation 125 ooo years ago need as boundary conditions, ice-sheet area for Earth albedo change, volume for sea-level change, and elevation for land-surface change. They want the minimum and maximum extremes for these changes. We think the $6 \mathrm{~m}$ higher sea-level then was caused by disintegration of the West Antarctic ice sheet. A minimum albedo change compared to present would result if ice shelves remained after the grounded ice sheet collapsed. We get that result by our ice-shelf disintegration model, which is so slow when ice shelves get bigger that isostatic rebound can almost keep pace with ice-sheet collapse. A maximum albedo change compared to present would result if ice shelves vanished after the grounded ice sheet collapsed. We get that result by our calving-bay disintegration model, which is so fast when ice shelves get smaller that the ice sheet has collapsed before significant isostatic rebound occurs. So we can satisfy the CLIMAP objectives without considering intermediate cases that involve lags in isostatic rebound.

Lliboutry: How could you use the creep law without any reference to temperature (which may not be the same, 18 ooo B.P. it could have been lower by $8 \mathrm{deg}$ )?

Hughes: The creep law for ice sheets 18 ooo years ago would give higher ice sheets for colder ice. So our ice elevations 18 ooo years ago are conservative, because we used the creep law fitted to present ice sheets.

LliboutRy: Which sliding law do you use? If you mean by "sliding" the deformation within a bottom layer, I do not know any simple sliding law. If "sliding" is taken in the same sense as in temperate glaciers, it needs not only a melting point at the interface, but a temperate bottom layer also (otherwise hillocks would protrude into cold ice and anchor the ice sheet), an uncommon circumstance.

Hughes: We used the sliding law of Weertman (I957). I agree that a temperate ice layer somewhat thicker than the "controlling obstacle size" is necessary. Like the ice hardness term in the flow law, we evaluated the bed roughness parameter in the sliding law by getting a "best-match" fit along present ice-sheet flow lines.

D. J. Drewry: What hard evidence do you have from, for instance, glacial-geologic data, isotopes, and total gas content, to test your reconstruction in areas such as the Ross Sea?

Hughes: The hard evidence for our Ross Sea reconstruction is based on George Denton's interpretation of the glacial-geological record along the Transantarctic Mountains and Tom Kellogg's interpretation of the marine micropaleontological record in the Ross Sea north of the Ross Ice Shelf. Their data and interpretations are in the process of being published.

DREWRY: I might mention that the sea-level curves computed by Lingle and Clark for McMurdo, based on your reconstruction and the Farrell-Clark model, predict emergence 
$50 \%$ greater than demonstrated by Denton's data on shells in deltas graded to sea-level. This might suggest that the reconstruction predicts too much ice in the Ross Sea.

C. S. LiNGLE: Use of the Farrell-Clark model to predict the global changes in relative sea-level caused by deglaciation of the Northern Hemisphere resulted in over-prediction of emergence for the Ottawa Islands, beneath the former Laurentide ice sheet in Hudson Bay, and for Inugsuin Fjord, near the former margin of Laurentide on Baffin Island (see Clark and others, I 978). McMurdo Sound is also beneath a formerly larger ice sheet. It is possible that over-prediction of emergence at McMurdo may be a result of errors in the ice history used as input to the Farrell-Clark model-i.e. less ice thinning than assumed may have occurred. It is also possible that the Farrell-Clark model consistently over-predicts emergence in areas beneath reduced or vanished ice sheets, because of approximations inherent in the Earth model - i.e. the mantle is assumed to be a viscous material, and the existence of the lithosphere is not taken into account.

D. E. Sugden: On your maps of maximum ice conditions in Antarctica and Greenland you show zones of melting and freezing. Am I right in thinking these zones are input to your model and if so where do they come from?

Hughes: The zones are input. They come from an interpretation of the role subglacial topography plays on melting and freezing beneath these ice sheets. This interpretation is compatible with zones predicted by the dynamic model of Budd and others (I97I) applied to Antarctica and the Laurentide ice sheet (Sugden, 1977). These zones have little effect on ice elevations along ice-sheet flow lines, so our ice-sheet reconstructions will not be changed if the distribution of zones is wrong. I might add that the purpose of assigning these or any other zones is to find out if they would influence ice elevations.

C. R. Bentley: What is the justification for the adoption of one model in which isostatic adjustment is entirely by lateral spreading in the upper rigid layer of the earth, with no depression into the much softer upper mantle? This model would appear to be geophysically completely unreasonable.

Hughes: Continents are about $30 \mathrm{~km}$ thick and the upper mantle does not get soft until the asthenosphere, about $200 \mathrm{~km}$ below the more rigid lithosphere. Internal radioactive heating of continental rocks would have to make them softer than the underlying lithosphere rocks for lateral continental spreading. If this is geophysically unreasonable, then glaciologists such as Weertman should abandon the practice of using models in which the weight of ice depresses the bed by one-third the ice thickness because ice has one-third the density of continental granitic rocks. In defence of Weertman, geophysicists find this unreasonable because they treat isostasy as if rock were a viscous fluid. Weertman (1978) says this is mechanically unreasonable. Rock is an elastic-viscoplastic material, and if rock is more plastic than viscous, isostatic readjustments may be more local.

V. K. Prest: In the case of the Laurentide ice sheet and an elongated dome extending from Keewatin (west of Hudson Bay) south-eastward to James Bay, with flow eastward from this dome, there is no geological evidence of drift dispersion toward the east or south-east.

Hughes: The "dome" is frozen to its base at steady state.

Prest: But drift is dispersed westward and south-westwards.

Hughes: This is disintegration dispersal.

Prest: Only partly so, as the dispersal distances demand long-continued flow over tens of thousands of years. 


\title{
REFERENCES
}

Budd, W. F., and others. 1971. Derived physical characteristics of the Antarctic ice sheet. Mark I, by W. F. Budd, D. Fenssen, and $U$. Radok. Melbourne, University of Melbourne. Meteorology Dept. (University of Melbourne. Meteorology Dept., Publication No. 18.)

Clark, J. A., and others. 1978. Global changes in post-glacial sea level: a numerical calculation, by J. A. Clark, W. E. Farrell, and W. R. Peltier. Quaternary Research, Vol. 9, No. 3, p. $265-87$.

Sugden, D. E. 1977. Reconstruction of the morphology, dynamics, and thermal characteristics of the Laurentide ice sheet at its maximum. Arctic and Alpine Research, Vol. 9, No. I, p. 21-47.

Weertman, J. 1957. On the sliding of glaciers. Fournal of Glaciology, Vol. 3, No. 21, p. 33-38.

Weertman, J. 1978. Creep laws for the mantle of the Earth. Philosophical Transactions of the Royal Society of London, Ser. A, Vol. 288, No. I350, p. 9-26.

\section{ISOSTATIC EQUILIBRIUM GROUNDING LINE BETWEEN THE WEST ANTARGTIC IGE SHEET AND THE ROSS ICE SHELF}

\author{
By C. R. Bentley and L. Greischar \\ (Geophysical and Polar Research Center, University of Wisconsin, Madison, Wisconsin 537o6, \\ U.S.A.)
}

Abstract. Taking various retreat-rates for the presumed grounded ice sheet in the Ross embayment during Wisconsin time, as calculated by Thomas (Thomas and Bentley, 1978), and assuming a time constant of 4400 years for isostatic rebound, a sea-floor uplift of $100 \pm 50 \mathrm{~m}$ still to be expected in the grid western part of the Ross Ice Shelf can be calculated. The expected uplift diminishes from grid west to grid east, and is probably negligible in the eastern half of the shelf area. There are extensive areas near the present grounding line where the water depth beneath the shelf is less than roo m, so that uplift would lead to grounding. As grounding occurred, the neighboring ice shelf would thicken, causing grounding to advance farther. This process would probably extend the grounding line to a position running grid north-eastward across the shelf from the seaward end of Roosevelt Island, deeply indented by the extensions of the present ice streams. Floating ice would remain in the grid south-eastern half of the shelf.

\section{REFERENCE}

Thomas, R. H., and Bentley, C. R. 1978. A model for Holocene retreat of the West Antarctic ice sheet. Quaternary Research, Vol. 10, No. 2, p. $150-70$.

\section{A NUMERIGAL INVESTIGATION OF THE LARGE SGALE DYNAMIGS OF SEA IGE}

\author{
By W. D. Hibler III* \\ (U.S. Army Cold Regions Research and Engineering Laboratory, Hanover, New \\ Hampshire 03755, U.S.A.)
}

Abstract. Several numerical simulations of the Arctic ice cover over a seasonal cycle are carried out. Two different types of constitutive laws are examined: rigid plastic and linear viscous. In both cases, the strength of the ice interaction is taken as a function of ice thickness

* Numerical simulations performed while on leave as a Visiting Fellow, Geophysical Fluid Dynamics Program, Princeton University, Princeton, New Jersey. 